Warszawskie Studia Pastoralne UKSW

Rok X 2015 Nr 4 (29)

WALtER KASPER

\title{
RAZ JESZCZE: DOPUSZCZENIE DO SAKRAMENTÓW ROZWIEDZIONYCH, KTÓRZY ZAWARLI NOWE MAŁŻEŃSTWO? CIERNISTY I KOMPLEKSOWY PROBLEM
}

Zagadnienie dopuszczenia do sakramentów osób rozwiedzionych, które zawarły nowy związek nie jest problemem nowym i tylko niemieckim. Dyskusja wokół tego zagadnienia toczy się od dziesięcioleci na forum międzynarodowym ${ }^{1}$. Jan Paweł II o dotychczasowej praktyce Kościoła zdecydował w adhortacji apostolskiej Familiaris consortio z roku 1981 (por. FC 84). W adhortacji apostolskiej Reconciliatio et paenitentia (1984) wyraźnie powtórzył to stanowisko (por. 34). Zostało ono podtrzymane również w 1993 r. w Katechizmie Kościoła Katolickiego (KKK 1650) oraz w Deklaracji Kongregacji Nauki Wiary z 19942. Papież Benedykt XVI potwierdził je w adhortacji apostolskiej Sacramentum caritatis z 2007 r. (por. SC, 29).

Jan Paweł II o problemie wyraził się jako o trudnym i jakby nierozwiązywalnym, zaś Benedykt XVI mówił o pełnym cierni, trudnym problemie. Nie może zatem dziwić, że do dziś dyskusja nad tą kwestią nie umilkła. Dotyczy bowiem nie tylko bezpośrednio zainteresowanych, ale też wielu praktykujących i zaangażowanych chrześcijan,

1 Stan dotychczasowej dyskusji przedstawiają: Karl Lehmann, Gegenwart des Glauben, Mainz 1974, s. 274-294, 295-308; Walter Kasper, Zur Theologie der christlichen Ehe, Mainz 1977, s. 55-83.

${ }^{2}$ Kongregacja Nauki Wiary, List do Biskupów Kościoła katolickiego na temat przyjmowania Komunii św. przez wiernych rozwiedzionych żyjących w nowych związkach, 14 IX 1994; por. Rudolf Voderholzer (Hg.), Zur Seelsorge wiederverheiratet Geschiedener. Dokumente, Kommentare und Studien der römischen Glaubenskongregation. Mit einer Einleitung v. Joseph Kardinal Ratzinger/Benedykt XVI, Würzburg 2014. 
którzy żyją w małżeństwie od pięćdziesięciu i więcej laty i sami nigdy nie myśleli o rozwodzie, ale boleśnie doświadczyli tego problemu u swoich dzieci czy wnucząt. Z kolei ich dzieci mają utrudnioną drogę do sakramentów, skoro ich rodzice nie mogą po niej kroczyć - tak więc cała rodzina dotknięta jest tym problemem. Nic więc dziwnego, że ciąży on na sumieniu wielu wiernych, duszpasterzy i spowiedników, teologów oraz biskupów.

Toteż oczekiwano, że w przededniu Nadzwyczajnego Synodu Biskupów 2014 i podczas jego trwania kwestia ta zapłonie nowym blaskiem i jako kontrowersyjna stanie się przedmiotem ożywionej dyskusji'. Zwyczajny Synod Biskupów 2015 winien przynieść propozycje rozwiązań, pozostawiając je ostatecznemu rozstrzygnięciu Papieża. Nie mogę i nie chcę antycypować decyzji przyszłego Zgromadzenia Biskupów. Chcę podjąć jedynie próbę, aby niniejszymi uwagami wyjaśnić i pogłębić - na ile jestem w stanie - istotę problemu.

\section{Słowo Jezusa - obowiązuje i zawsze stanowi nowe wyzwanie}

Podstawą jest słowo Jezusa, które mówi, że nie wolno człowiekowi rozłączyć tego, co Bóg złączył. Prawda ta znajduje się we wszystkich Ewangeliach synoptycznych (Mt 5,32; 19,9; Mk 10,9; Łk 16,18). Poświadczona jest także przez Apostoła Pawła (1 Kor 7,10n) ${ }^{4}$. Nie może

3 Walter Kasper, Das Evangelium von der Familie. Die Rede vor dem Konsistorium, Freiburg 2014. Mój odczyt traktuje o problemie rozwiedzionych żyjących w nowych związkach w ostatnim rozdziale (54-67) i tylko w niewielkim stopniu. Miał on jedynie wywołać dyskusję - samego rozwiązania nie przedstawiłem. Poszczególne kwestie spotkały się z uznaniem, ale też i z krytyką. W niniejszych uwagach nie odnoszę się bezpośrednio do tej krytyki, lecz tylko pośrednio, wyjaśniając swoje stanowisko wobec licznych nieporozumień oraz kontynuując i pogłębiając własne przemyślenia.

${ }^{4}$ Owoce dyskusji między egzegetami nad słowem Jezusa są nieprzebrane. Odnośnie starszych stanowisk por. przyp. 1. Przegląd najnowszej dyskusji u Ulrich Luz, Das Evangelium nach Matthaus, Mt 1-7 (EKK Bd. I/1), Würzburg 1997, s. 88-103. Ponieważ dotychczas ukazało się mnóstwo przyczynków, wystarczyć musi wskazanie tylko niektórych: Markus Graulich, Martin Seidnader (Hg.), Zwischen Jesu Wort und Norm. Kirchliches Handel angesichts von Scheidung und Wiederheirat (QD 264), Freiburg 2014 z artykułami: Dominik Markl SJ i Thomas Söding; por. Konrad 
istnieć żadna rozumna wątpliwość, że w swej substancji sięga ona do samego Jezusa. W swym niesłychanym radykalizmie takie słowa Jezusa wydają się gorszące nie tylko dzisiaj. Już pierwsi uczniowie byli nimi zszokowani, a dla ówczesnego hellenistyczno-rzymskiego świata stanowiły totalną prowokację. Jak wówczas, tak i dziś w znikomym stopniu możemy złagodzić słowo Jezusa przystosowując je do sytuacji.

Jezus odrzucił tym samym odwołującą się do Pwt 24,1 żydowską kazuistykę, nie uznając równocześnie wszelkiej innej kazuistycznej interpretacji oraz wyjątkowej regulacji odnośnie pierwotnej woli Bożej. Zatem słowo Jezusa nie jest wypowiedzią o charakterze prawnym, ale zasadą, dzięki której Kościół wraz z udzieloną mu przez Chrystusa władzą związywania i rozwiązywania (Mt 16,19; 18,18; J 20,23) musi zapewnić skuteczność w zmiennych sytuacjach kulturowych.

Dlatego słowa Jezusa nie wolno interpretować na sposób fundamentalistyczny. Ważne jest badanie granic tego słowa oraz jego zasięg, by w całości móc pojąć to Jezusowe przesłanie i zachować mu wierność, nie popełniając przy tym nadużyć ${ }^{5}$. Taką właściwą interpretację znajdujemy już w czasach nowotestamentowych: w znanych klauzulach cudzołóstwa przeznaczonych dla żydowskiej gminy Mateusza $(5,32 ; 19$,), u Pawła, który w nowym pogańsko-chrześcijańskim środowisku władzą apostolską zdecydował na rzecz wolności chrześcijańskiej, że małżeństwo, w którym partner niewierzący odmawia życia w należyty sposób z partnerem chrześcijańskim (1 Kor 7,12-16), może być rozłączone. Stało się to później podstawą dla tzw. privilegium Paulinum, a jeszcze później dla privilegium Petrinum

Hilpert, Scheidung und Wiederheirat zwischen Jesu Wort und Norm, [w:] Stimmen der Zeit 233 (2015) 3, s. 338-341; Guido Innozento Gargano, Il mistero delle nozze cristiane. Tentativo di approfondimentio biblico-teologico, [w:] Urbaniana University Journal 3 (2014), s. 51-73.

5 Joseph Ratzinger, Zur Frage nach der Unauflöslichkeit der Ehe. Bemerkungen zum dogmengeschichtlichen Befund und zu seiner gegenwärtigen Bedeutung, [w:] tenże, Gesammelte Schriften, Bd. 4: Einführung in das Christentum. Bekenntnis - TaufeNachfolge, Freiburg 2014, s. 600-621; por. tenże, Zur Theologie der Ehe, [w:] tamże, s. 565-592, 589-591; tenże, Rückblick auf die Bischofssynode zu Ehe und Familie 1980, [w:] tamże, s. 622-649, 633n. 
dając możliwość rozwiązania ważnie zawartego małżeństwa sakramentalnego - choć niedopełnionego - na mocy władzy Kościoła do związywania i rozwiązywania.

Okoliczności te są ważną przesłanką dla zrozumienia zmiennej praktyki pastoralnej niektórych lokalnych gmin wczesnego Kościoła. Interpretacja odpowiednich tekstów jest sporna wśród specjalistów ${ }^{6}$. $\mathrm{Na}$ żadnej z tych hipotez nie sposób wypracować dziś rozwiązania dla Kościoła. Interesujące jest wszakże, że problemu tego byli świadomi ojcowie Soboru Trydenckiego. Nauczali oni mianowicie przeciw nauce Lutra, że Kościół nie myli się, jeśli nie uznaje drugiego małżeństwa (DH 1807); tym samym świadomie nie potępili różnych prawosławnych praktyk ${ }^{7}$. Nauczali o nierozerwalności ważnie zawartego małżeństwa (DH 1797n; por. 794; 3710n), formalnie nie definiując tej nauki ${ }^{8}$. Jest ona jednak obowiązującą nauką wiary, o której stale należy pamiętać i która zawsze stanowi nowe wyzwanie.

${ }^{6}$ Literatura - przyp. 1, zwłaszcza Henri Crouzel, L'Eglise primitive face au divorce. Du premier au einquieme siecle, Paris 1971; inaczej: Giovanni Cereti, Divorzio, nuove nozze e penitenza nella Chiesa primitiva, Bologna $1977\left(2013^{3}\right)$; tenże, Divorziati risposati. Un nuovo inizio e possibile?, Assisi $2014^{2}$. W żadnym razie nie utożsamiam się ze stanowiskiem Cereti'ego. Jednak nie mogę zgodzić się z ujęciami o charakterze apologetycznym, które przeciwne do dzisiejszej praktyki teksty rozmywają przez przypisywanie im przyjętych później teorii.

7 Wykazał to jeszcze raz Klaus Ganzer na podstawie historii tekstu kanonu 7 Dekretu o sakramencie matżeństwa (DH 1807), Absolute Unauflöslichkeit der Ehe auf dem Konzil von Trient? Zur Frage einer neuen Eheschliessung bei Ehebruch auf dem Konzil, (publikacja własna 2015). Powołał się on przy tym na publikację Luigi Bressa, Il canone tridentino sul divorzio per adulterio e l'interpretazione degli autori, Rom 1973 i Huberta Jedina, Geschichte des Konzil von Trient, Bd. 3, Bologneser Tagung (1547/48) - Zweite Trienter Tagungsperiode (1551/52), Freiburg 1970, s. 141-161; tenże, Bd. 4/2: Überwindung der Krise durch Morone, Schliessung und Bestätigung, Freiburg 1975, s. 96-121, zwłaszcza 108n.

8 Franz Diekamp, Klaudius Jussen (Katholische Dogmatik nach den Grundsatzen des heiligen Thomas, Bd. 3 Münster 1962 $2^{13}$ ) i Joseph Pohle, Josef Gummersbach (Lehrbuch der Dogmatik, Paderborn $1956^{10}$ ) mówią o sententia fidei proxima, Ludwig Ott (Grundriß der katholischen Dogmatik, Freiburg $1981^{10}$ ) tylko o sententia certa. 


\section{Małżeństwo - niedoskonały znak przymierza}

Sobór Watykański II podjął to wezwanie. Pominął pojmowanie małżeństwa jako kontraktu - wypracowane przez prawo rzymskie - dając pierwszeństwo rozumieniu zgodnemu z nauką Tomasza z Akwinu', w analogii do biblijnej teologii przymierza jako wewnętrzną wspólnotę życia i miłości, w której małżonkowie wzajemnie się sobie oddają i przyjmują (por. Gaudium et spes, 47). Wraz z tym całkowicie osobowym rozumieniem małżeństwo interpretuje się w nawiązaniu do Ef 5,25 jako sakramentalny obraz przymierza Chrystusa z Kościołem. Odpowiednio wzajemny stosunek mężczyzny i kobiety powinien być odwzorowaniem stosunku Chrystusa i Kościoła.

Dla nauki Kościoła i dla nowszej teologii soborowa nauka o małżeństwie zakotwiczona w biblijnym przymierzu stała się decydująca. Z niej wynika głębsze uzasadnienie nierozerwalności małżeństwa. Jak przymierze Boga w Jezusie Chrystusie z Kościołem jest definitywnie nierozerwalne, tak też nierozerwalne jest przymierze małżeńskie będące rzeczywistym symbolem tego przymierza ${ }^{10}$.

Jest to koncepcja wspaniała i przekonywująca. Nie może jednak prowadzić do obcej życiu idealizacji. W Liście do Efezjan mowa jest, że Chrystus umiłował Kościół, poświęcił się dla niego, i że w wodzie i przez słowo uczynił czystym i świętym, by stał się wspaniały, bez skazy i zmarszczki, święty i nieposzlakowany $(5,24-27)$. Nie jest to opis stanu, ale eschatologiczna obietnica, do której Kościół dopiero

9 Por. szczegółowe badania Adriano Oliva, Essence et finalite du mariage selon Thomas d'Aquin pour un soin pastoral renouvele, [w:] Revue sciences phil. et. theol., 98 (2014), s. 601-668.

10 FC 12n, SC 27. Gdy idzie o teologiczną recepcję ograniczę się do wskazania dwóch różnych autorów: Eberhard Schockenhoff, Chancen zur Versöhnung? Die Kirche und die wiederverheirateten Geschiedenen, Freiburg 2011, s. 73-98; Marc Quellet, Die Familie - Kirche im Kleinen. Eine trinitarische Anthropologie, Einsiedeln 2013; tenże, Misterio e sacramento dell'amore. Teologia del matrimonio e della famiglia per la nuova evangelizzazione, Sienna 2007 (Mystery and Sacrament of Love. A theology of Marriage and the Family for New Evangelization, Grand Rapids 2015); tenże, Ehe und Familie im Rahmen der Sakramentalität. Herausforderungen und Perspektiven, IkaZ 43 (2014), s. 413-428. 
zmierza. W swym ziemskim pielgrzymowaniu Kościół może urzeczywistniać swoją świętość jedynie na sposób niedoskonały. Będąc świętym jest on także Kościołem grzeszników, który niczym niewierna nierządnica zawsze musi podążać drogą nawrócenia, odnowy i reformy (por. Lumen gentium, 8, Unitatis redintegratio, 4).

Odnosi się to także do chrześcijańskiego małżeństwa. Jest ono wielką tajemnicą (mysterion) odnośnie do Chrystusa i Kościoła (Ef 5, 32). W życiu małżeństwo nie może jednak urzeczywistnić tej tajemnicy w sposób całkowity, lecz zawsze jedynie niedoskonały. W tym sensie jest ono tylko niedoskonałym znakiem przymierza. Małżonkowie będąc na tej drodze, podlegają prawu stopniowania (por. FC 9, 34). Stale potrzebują nawrócenia i pojednania i ciągle na nowo zdani są na Boga, który jest bogaty w miłosierdzie (Ef 2, 4; por. FC 38).

Dramat może doprowadzić do tego, że również chrześcijanie doznają niepowodzenia w małżeństwie. Niepowodzenie to stanowi katastrofę, w której projekt życia ze wszystkimi nadziejami załamuje się i obraca wniwecz. Takie niepowodzenie także należy do biblijnej teologii przymierza. W sposób nader dramatyczny zostało to ukazane u proroka Ozeasza. Najpierw widzimy obraz: Izrael stał się nierządnicą; Bóg ostatecznie wypowiedział Przymierze (Oz 1,9; 2,4-15). Następnie jednak słuszny gniew Boga ustępuje miejsca miłosierdziu. Ofiarowuje On swemu ludowi nowy początek (11, 8n; por. 2, 16-25). Wobec Jezusowego orędzia lud znowu w większości zawodzi. Jezus zdecydowanie poddaje krytyce tę zatwardziałość serc. Jednak wówczas Jezus przez Krzyż i Zmartwychwstanie funduje nam Nowe Przymierze. Daje obiecane przez proroków nowe serce (Ez 36, 6n; por. Jer 31, 33; Ps 51, 12). Wszak zatwardziałość serc (Mt 19, 8) trwa nadal w grzeszności chrześcijan. Bóg jednak pozostaje wierny, mimo naszej niewierności. Jego miłosierdzie jest bez granic.

Realistyczna teologia małżeństwa musi przemyśleć to niepowodzenie oraz możliwość przebaczenia ${ }^{11}$. Także bowiem w ludzkich niepowodzeniach pozostaje obietnica wierności Boga i Jego miłosierdzia. $\mathrm{W}$ tym sensie nauka o nierozerwalności małżeństwa staje się na nowo

11 Eberhard Schockenhoff (przyp. 9), s. 99-125. 
aktualna. Nie jest ona czystym ideałem. Boże „tak” pozostaje, mimo, że ludzkie "tak” jest słabe albo zgoła niedoskonałe. Wpisane jest to na stałe w historię wolności małżonka. Węzeł małżeński zawiązany przez samego Boga nie ulega zerwaniu, natomiast ludzka miłość słabnie czy zupełnie gaśnie. Jednak w sytuacji ludzkiego niepowodzenia w małżeństwie sytuacja nigdy nie jest bez wyjścia i beznadziejna. Bóg również w sytuacjach, w których my nie widzimy żadnego wyjścia, może otworzyć nową drogę. Poleganie wspiera się na Bożym miłosierdziu, o ile tylko polegamy na miłosierdziu. ${ }^{12}$.

Owa realistyczna - by tak rzec - odporna na kryzys teologia przymierza stawia Kościół przed pytaniem: w jaki sposób może on, rozumiejąc siebie jako sakrament Bożego miłosierdzia, ludziom, którzy w swym małżeństwie doznali bolesnej klęski towarzyszyć na nowej drodze oraz ofiarować im nową nadzieję?

\section{Komunia duchowa - drogą wyjścia?}

Kościół w sytuacji rozbitych małżeństw, także wobec rozwiedzionych, którzy zawarli nowy związek nie znajduje się w pastoralnej próżni. Nowsze dokumenty Kościoła stanowczo domagają się, by w takich bolesnych sytuacjach szczególnie zwrócić się ku dotkniętym nimi ludziom i zaprosić ich do udziału w życiu Kościoła (por. FC 83n, SC 29). Często takim ludziom próbuje się otworzyć drogę z Chrystusem i w Chrystusie, przywołując przy tym ideę Komunii duchowej.

Wraz z pojęciem Komunii duchowej nawiązuje się ostatnio do zapomnianego, niestety, bogactwa tego znanego w Tradycji Kościoła pojęcia $^{13}$. W dokumentach Soboru Watykańskiego II oraz w Ka-

\footnotetext{
12 Por. do tego liczne wypowiedzi papieża Franciszka, zwłaszcza w adhortacji apostolskiej Evangelii gaudium (2013) i bulli Misericordiae Vultus (2015).

13 Johann Auer, Geistige Kommunion. Sinn und Praxis der communio spiritualis und ihre Bedeutung für unsere Zeit, [w:] GuL 24 (1951), s. 113-132; Louis de Bazelaire, Communion spirituelle, [w:] Dictionnaire de Spiritualite 22 (1953), s. 1294-1301; Heinz Robert Schlette, Kommunikation und Sakrament, Freiburg 1959 (z liczną znacznie starszą literaturą); Robert Taft, Receiving Communion. A Forgotten Symbol?, [w:] Worship 57 (1983), s. 412-418; Benoit-Dominique de La Soujeole, Communion sacramentelle et communion spirituelle, [w:] Nova et Vetera, 86 (2011), s. 147-153; Paul
} 
techizmie Kościoła Katolickiego, niestety, nie występuje. Dopiero najnowsze dokumenty Magisterium Kościoła przywołują to pojęcie ${ }^{14}$, rozumiejąc przez nie pewną drogę wyjścia w „ciernistych” sytuacjach osób rozwiedzionych, żyjących w nowych związkach ${ }^{15}$.

Tradycja Komunii duchowej sięga początkami wielkiej Mowy Eucharystycznej z 6 rozdziału Ewangelii Jana oraz jej wykładni dokonanej przez Augustyna. Mówi się tam o Chlebie Życia, którym jest Jezus Chrystus, a w Którym poprzez wiarę mamy udział ${ }^{16}$. W późnym średniowieczu nauka o Komunii duchowej znajduje swoje miejsce zwłaszcza u Tomasza z Akwinu ${ }^{17}$. Sobór Trydencki oficjalnie przyjął tę naukę (por. DH 1648, 1747). Implikuje ona trojakie znaczenie: pragnienie Komunii sakramentalnej (komunii in voto czy cum desiderio), duchowe otrzymanie Komunii sakramentalnej (manducatio spiritualis) i wreszcie zdobywany przez akty osobistej pobożności - przede wszystkim w adoracji Eucharystii - wzrost Komunii sakramentalnej.

Właściwie rozumiana Komunia duchowa nie jest alternatywną formą Komunii sakramentalnej, lecz w istotny sposób odnosi się do Komunii sakramentalnej. Tak zatem problematyczne staje się jej zastosowanie w sytuacji osób rozwiedzionych ponownie zawierających nowe związki. Czy można ją więc zalecać jako alternatywną drogę

Jerome Keller, Is Spiritual Communion for Everyone?, [w:] Nova et Vetera (engl. e.) 12 (2014), s. 631-655; Giancarlo Pani, La comunione spirituale, [w:] Civilta Cattolica 3957 (2015 II), s. 224-237; Paul Josef Cordes, „Geistige Kommunion“. Befreit vom Staub der Jahrhunderte, Kislegg 2014.

14 Jan Paweł II, Adhortacja apostoska Ecclesia de Eucharistia (2003, 34); SC 55. Der deutsche katholische Erwachsenenkatechismus był pod tym względem pierwszy: Deutsche Bischofskonferenz (Hg.), Katholischer Erwachsenenkatechismus, Bd. 1: Das Glaubensbekenntnis der Kirche, Freiburg 1985, s. 357.

15 Wpierw przez Kongregację Nauki Wiary (przyp. 2, nr 7). Benedykt XVI podczas VII Światowego Spotkania Rodzin w Mediolanie z 1-3.VI. 2012 powiedział w odniesieniu do rozwiedzionych, którzy zawarli nowy związek: „Także bez tego, 'cielesnego' przyjmowania Sakramentu możemy być duchowo zjednoczeni z Chrystusem w jego Ciele."

16 Rudolf Schnackenburg, „Geistliche Kommunion” und Neues Testament, [w:] GuL 23 (1952), s. 407-411; Augustinus, In Io. tract. 25, 12.

17 Thomas von Aquin, S. theol. III q. 80 a. 1.2. 
do Komunii sakramentalnej? Z pewnością nie. Sprzeciwiałoby się to sakramentalnemu rozumieniu siebie przez Kościół katolicki jako widzialnemu sakramentowi, to znaczy jako znakowi i narzędziu łaski. Nadto istnieje inna jeszcze trudność: kto przyjmuje Komunię duchową i w wierze pozostaje zjednoczony z Chrystusem, nie może jednocześnie znajdować się w stanie grzechu ciężkiego. Dlaczego nie może on wówczas uczestniczyć także w Komunii sakramentalnej? Tak więc zastosowanie Komunii duchowej w przypadku rozwiedzionych żyjących w nowym związku, jeśli wychodzi się z jej tradycyjnego rozumienia, prowadzi do teologicznej ślepej uliczki ${ }^{18}$.

Natomiast możliwa jest taka droga, jeśli Komunii duchowej nadać nowy sens. W tym nowym sensie nie rozumie się jej jako pragnienia wynikającego z bycia w jedności z Chrystusem poprzez wiarę zgodnie z Komunią sakramentalną, ale jako pragnienie, w którym żyjący w nieregularnej sytuacji chrześcijanin jest świadomy swego oddzielenia od Chrystusa, i że to jego pragnienie - dopóki nie zmieni zasadniczo swej obecnej sytuacji - nie może być spełnione. Tak rozumiana Komunia duchowa może stać się zbawczym impulsem do metanoia (nawrócenie). Dlatego też to nowe rozumienie pozostaje faktycznie możliwe. Niesie jednak za sobą pojęciowe nieporozumienie. Tradycja Kościoła może nam zaoferować klarowną drogę.

\section{Ku odnowie via paenitentialis}

Kościół starożytny podczas prześladowań już bardzo wcześnie boleśnie doświadczył różnych załamań wśród chrześcijan. W czasach prześladowań wielu chrześcijan ulegając słabościom wypierało się chrztu. Doprowadziło to później do gwałtownej dyskusji, w jaki mianowicie sposób Kościół powinien postępować w takich sytuacjach. Ojcowie Kościoła na Wschodzie i Zachodzie wobec jednoznacznego rygoryzmu Nowacjana (zm. ok. 258), stawiającego wysoko ideał Kościoła

\footnotetext{
18 Ze względu na tą ślepą uliczkę nie krytykowałem Komunii duchowej, której praktykowanie jest duchowo wartościowe i jako takie domaga się odnowienia, ale jej powodujące nieporozumienia zastosowanie do sytuacji osób rozwiedzionych w nowych związkach.
} 
jako nieskalanej dziewicy, bronili obrazu Kościoła jako miłosiernej matki, którego drzwi dla nawracających się grzeszników są stale szeroko otwarte. Przyjęli oni pokutę kanoniczną, którą pojmowali nie jako drugi chrzest $\mathrm{z}$ wody, ale jako chrzest $\mathrm{z}$ łez żalu i pokuty. Tak więc Kościół poważnie przyjął swą władzę rozgrzeszania grzechów i swą służbę na rzecz pojednania (2 Kor 5,20). Na mocy sakramentu pojednania po rozbiciu się okrętu grzeszników nie udzielali oni drugiego chrztu, ale - by tak rzec - burtę ratunkową, ratującą przed utonięciem i zapewniającą przeżycie ${ }^{19}$.

Podobne postępowanie stosowali poszczególni ojcowie wobec chrześcijan, którzy rozbili własne małżeństwo, żyli w drugim związku i na drodze pokuty pojednali się z Kościołem, zostając dopuszczeni do Komunii ${ }^{20}$. Kościół wschodni tą drogą poszedł jeszcze dalej ${ }^{21}$. W ramach liturgii pokutnej zezwalał na zawarcie drugiego i trzeciego małżeństwa, które - choć równe jest obrzędom „koronowania” rozumiane jest nie jako sakrament, ale błogosławieństwo. Z prawodawstwa cesarstwa bizantyjskiego przejął odnośnie do klauzuli nierządu z Ewangelii Mateusza także inne powody dla orzeczenia rozwodu. Praktyka ta opiera się na zasadzie oikonomia, zorientowanej na miłosiernych czynach Boga dokonanych w całej historii zbawienia. Kościół zachodni nie przyjął tej praktyki, rozwijając własne prawo małżeńskie niezależnie od prawa bizantyjskiego.

Często podnosi się pytanie czy Kościół zachodni powinien przyjąć tę prawosławną praktykę. Z pewnością może się on uczyć prawosławnego pojmowania oikonomia. Jednak dalszy rozwój jego prawa małżeńskiego musi dokonywać się raczej w pierwszym rzędzie w duchu własnej tradycji kanonicznej, które nie zna liturgicznej formy drugiego małżeństwa. Natomiast wschodniej zasadzie ekonomii

\footnotetext{
19 Zob. znane studia Bernharda Poschmanna, Karla Rahnera SJ, Herberta Vorgrimlera i innych.

20 Zwłaszcza Bazyli z Cezarei; por. J. Ratzinger, Unauflöslichkeit (przyp. 5), s. 600-606.

${ }^{21}$ Co do Tradycji wschodniej m. in. Basilio Petra, Divorziati riposati e secondo nozze nella chiesa. Una nuova soluzione, Assimi 2012; tenże, Divorzio e secondo nozze nella tradizione greca. Un'altra via, Assisi 2014.
} 
odpowiada pod wieloma względami w Tradycji zachodniej zasada epikie ${ }^{22}$. W rozumieniu Tomasza z Akwinu nie jest ona prawnym wyjątkiem, unieważnieniem przepisu prawnego (derogacja), ale wyższą sprawiedliwością, która w przypadku zawiłych sytuacji, kiedy dosłowna, dokładna wykładnia prawa byłaby niesprawiedliwa (niesłuszna), zapewnia prawu w miłosierny sposób skuteczność na sposób „słuszny i sprawiedliwy”23.

Słuszność w średniowiecznej kanonistyce rozumiano jako iustitia dulcore misericordiae temperata, co w wolnym tłumaczeniu oznacza: sprawiedliwość, jaka konkretne zastosowanie znajduje dzięki czułości miłosierdzia i mierze w oku. W tym sensie Kościół w trudnych sytuacjach mógł łączyć w miłosierny sposób władzę związywania i rozwiązywania. Nie chodzi przy tym o wyjątki prawne, ale o właściwe oraz miłosierne stosowanie prawa.

Nie ma tu miejsca dla taniego (pseudo)miłosierdzia. Pozostaje, oczywiście, ważna zasada z 1 Kor 11, 28: kto uparcie, to znaczy bez woli nawrócenia, trwa w grzechu ciężkim, nie może uzyskać rozgrzeszenia i tym samym nie może być dopuszczony do przyjęcia Komunii (KPK/1983, kan. 915). Zasada ta jest oczywista i bezsporna. Pozostaje jednak konkretne pytanie, kto faktycznie w sposób uparty znajduje się w takiej „antyzbawczej” sytuacji, które nie jest tym samym rozstrzygnięte. Aby na nie odpowiedzieć, ważne jest, aby dobrze rozróżnić odmienne sytuacje oraz każdą taką poszczególną sytuację dyskretnie i taktownie zbadać (por. FC 4, 84). Nie można mówić o obiektywnym stanie grzechu, nie badając sytuacji grzesznika w jego jednorazowej, osobistej godności. Z tego powodu ogólne rozwiązanie problemu nie jest możliwe, a jedynie rozwiązanie dla konkretnego przypadku.

\footnotetext{
22 Thomas von Aquin, S. theol. II/II 120n; por. Gunter Virt, Epikie - verantwortlicher Umgang mit Normen. Eine historisch-systematische Untersuchung, Mainz 1983; tenze, Moral Norms and the Forgotten Virtue of Epikeia in the Pastoral Care of the Divorced and Remarried, [w:] Journal of the Faculty of Theology University of Malta 63/1 (2013), s. 17-34.

${ }^{23}$ Odnośnie teorii aplikacji norm kanonicznych por. Walter Kasper, Barmherzigkeit. Grundbegriff des Evangeliums - Schlüssel christlichen Lebens, Freiburg 2012, s. 174177, 238, przyp. 174.
} 
Wynika to także z samego pojęcia grzechu ciężkiego. Do grzechów ciężkich należy nie tylko materia gravis, wykroczenie przeciwko przykazaniu Bożemu w materii o dużym ciężarze gatunkowym; należą do nich także osąd własnego sumienia, zgoda woli - dla Tomasza intencja woli jest już całkiem rozstrzygająca; wreszcie ważne pozostaje uwzględnienie konkretnych okoliczności ${ }^{24}$. O tym wszystkim nie sposób ogólnie rozstrzygać. Dlatego też mądrość Kościoła obok prawnego forum zewnętrznego zna także forum wewnętrzne, to jest forum sakramentu pokuty.

Stoimy tym samym przed via paenitentialis. Nie jest ona modnym wynalazkiem, ale - jak to ostatnio wykazano - leży na linii rozumienia małżeństwa Tomasza z Akwinu oraz tradycji, której dał początek - zwłaszcza Soboru Trydenckiego ${ }^{25}$. Nie chodzi tu o odbycie nałożonej pokuty, ale o bolesny - choć zbawienny - proces przeżywania i swego rodzaju wychodzenia z katastrofy rozwodu, któremu towarzyszy doświadczony spowiednik w cierpliwym wsłuchiwaniu się w sytuację osoby zainteresowanej i rozmowy $\mathrm{z}$ nią. Ten proces powinien doprowadzić u zainteresowanego do rzetelnego osądu własnej sytuacji; także spowiednik dochodzi w nim do duchowego osądu, pozwalającego mu na właściwe i odpowiednie do każdorazowej indywidualnej sytuacji skorzystanie z władzy związywania i rozwiązywania. Tak miało to miejsce w najtrudniejszych sytuacjach zgodnie ze starożytną praktyką Kościoła i podporządkowane było autorytetowi biskupa.

Pozostaje dla mnie zagadką, jak można występować przeciwko takiej propozycji, twierdząc, jakoby chodzić tu miało o przebaczenie bez nawrócenia. Twierdzenie takie w rzeczywistości jest teologicznym bezsensem. Sakrament pokuty implikuje bowiem ze strony penitenta żal i wolę, aby w nowej sytuacji starać się ze wszystkich sił żyć zgodnie $\mathrm{z}$ Ewangelią ${ }^{26}$. W akcie rozgrzeszenia następuje usprawiedliwienie

\footnotetext{
${ }^{24}$ KKK 1857-1860; Thomas von Aquin, S. theol. I/II, 19,5; 72,5.

25 Do takich wniosków dochodzi Oliva (przyp. 9), s. 650-663.

${ }^{26}$ Jan Paweł II rozstrzygnął (por. FC 84), że rozwiedzeni, którzy zawarli nowe związki i prowadzą życie nie będące w sprzeczności z nierozerwalnością małżeństwa,
} 
nie grzechu, ale nawróconego grzesznika. Komunia sakramentalna, do której uprawnia rozgrzeszenie, winna dać człowiekowi siły do znoszenia trudów na jego nowej drodze. Właśnie chrześcijanie znajdujący się w trudnej sytuacji zdani są na to źródło mocy, jakim jest dla nich Chleb Życia.

Taka odnowa praktyki pokutnej Kościoła mogłaby spotkać się z oddźwiękiem wykraczającym poza kategorię osób rozwiedzionych żyjących w nowych związkach na rzecz koniecznej odnowy chorej i pożałowania godnej w dzisiejszym Kościele pokuty. Byłoby przecież faryzeizmem sądzić, że to wszystko miałoby dotyczyć tylko chrześcijan rozwiedzionych, którzy zawarli nowy związek. Refleksja

to znaczy jeśli żyją oni w zupełnej wstrzemięźliwości, mogą otrzymać sakrament pokuty i Eucharystii. Chrześcijanie, którzy zdecydowali się na taką drogę i postępują nią mimo wszelkich, związanych z tym, trudności, dają wyraźne świadectwo jedności i nierozerwalności małżeństwa; ich wielkoduszne świadectwo zasługuje na wielki respekt i domaga się wyrozumiałego towarzyszenia pastoralnego. Z drugiej strony ta wyjątkowa regulacja z FC 84 rodzi teologiczne pytania. Według Tomasza z Akwinu istota małżeństwa mieści się w duchowej wspólnocie; seksualne zjednoczenie jest według niego wtórne (S. theol. III, 20,2: Supplementum 44,1). Idąc za tym poglądem, pojawia się wówczas pytanie: czy jest sensowne, a nawet czy nie jest sprzeczne, aby ten wyraźny w cywilnym małżeństwie istotny element małżeństwa - by tak rzec - jako rozwiązanie kompromisowe (bariera zbawienia!) milcząco przynajmniej tolerować, aby z kolei - wynikające z tego - wykluczenie elementu wtórnego uczynić kryterium dopuszczenia bądź niedopuszczenia do sakramentów? Mówiąc inaczej: owo należące do zakresu intymnego zjednoczenie seksualne, rozpatrywane w aspekcie sakramentalnym, nie stoi na przeszkodzie znakowi sakramentalnemu, ale przez tę wyjątkową regulację przynajmniej milcząco tolerowałoby na sposób cywilnoprawny publicznie uznaną wspólnotę życia jako małżeństwo. Jeśli małżeństwo cywilne jest tolerowane, wówczas pojawia się pytanie, czy można uczynić generalnym kryterium przyporządkowanej zakresowi intymnemu a więc "forum internum" kwestię wstrzemięźliwości, bez zbadania konkretnej sytuacji wobec ciężko grzesznemu sposobowi życia i uczynić decydującym kryterium dopuszczenia bądź niedopuszczenia do otrzymania sakramentów. W tym punkcie musi dokonać się dalsza dyskusja oraz trzeba pytać, czy wyjątkowa regulacja z FC 84 dotycząca wewnętrznej teologicznej logiki rzeczy nie wymaga dalszej refleksji. Ostatecznie chodzi tu o godność i niepowtarzalność każdej osoby oraz o jej sumienie w koniecznym rozróżnianiu zewnętrznego i wewnętrznego forum. 
nad tezami Lutra, które to przed 500 laty dały początek Reformacji, skłania katolików i ewangelików do przywołania pierwszej z nich, mówiącej, że całe życie chrześcijanina powinno być pokutą.

\section{Hermeneutyka kontynuacji}

Zamykając zagadnienie: czy dalszy rozwój praktyki pokutnej w kierunku, o którym powiedziano wyżej, byłby naruszeniem nauki i praktyki Kościoła czy raczej należałoby go rozumieć w sensie hermeneutyki kontynuacji? Właściwie rozumiana hermeneutyka kontynuacji zaprezentowana przez Benedykta XVI w znanym przemówieniu z okazji świąt Bożego Narodzenia w 2005 r., nie wyklucza praktycznych reform, a tym samym momentu dyskontynuacji, ale je dopuszcza ${ }^{27}$.

Prawda Objawienia nie jest wszak wyżłobionym w kamieniu skostniałym systemem, ale przez Ducha Boga żywego napisanym do serc z ciała listem miłości Boga (por. 2 Kor 3,3). Bóg przez swojego Ducha nieustannie pozostaje z Kościołem w dialogu, z Oblubiennicą swojego Syna, aby ciągle na nowo prowadzić go do pełni Prawdy $(J 16,13)$ oraz do zawsze tej samej Ewangelii, by odkrywać jej wieczną nowośćc ${ }^{28}$.

Miłosierdzie jest tą wieczną nowością. W nim objawia się suwerenność Boga, w swej istocie będąca Miłością (1 J 4,8), który ciągle na nowo wierny jest swojemu Przymierzu. Miłosierdzie jest Objawieniem wierności i tożsamości Boga z samym sobą, a przez to równocześnie legitymacją chrześcijańskiej tożsamości ${ }^{29}$. Dlatego miłosierdzie nie stoi naprzeciw chrześcijańskiej prawdzie. Wszak ono samo jest Prawdą objawioną, pozostając w nierozerwalnym

\footnotetext{
27 Przemówienie Benedykta XVI do Kolegium Kardynałów i członków Kurii Rzymskiej z okazji Świąt Bożego Narodzenia, 22.XII.2005. Praktycznie papież Benedykt XVI uczynił dalece własnym stanowisko Johna Henry Newmanna: An Essay on the Development of Christian Doctrine, London 1878.

${ }^{28}$ O rozwoju nauczania: Sobór Watykański I, Konstytucja Dogmatyczna Dei Filius (DH 3020); Sobór Watykański II, Konstytucja Dogmatyczna Dei Verbum (8); o wiecznej nowości Ewangelii papież Franciszek, Adhortacja apostolska Evangelii gaudium (11).

${ }^{29}$ Walter Kasper, (przyp. 22); tenże (przyp. 3), s. 55n.
} 
związku z podstawowymi prawdami wiary: Wcieleniem, śmiercią i Zmartwychwstaniem Chrystusa. I odwrotnie: wszystkie te prawdy bez czułości miłosierdzia staną się skostniałym i zimnym systemem. Miłosierdzie pozwala w zaskakujący sposób, ciągle na nowo zajaśnieć, przydając wierze nieustannie nową siłę promieniowania. Tylko tak może się udać nowa ewangelizacja.

Przynaglenie, by „trwać w prawdzie Chrystusa” mieści inne: „trwać w miłości Chrystusa" (J 15,9). Obowiązuje czynienie prawdy w miłości (por. Ef 4,15).

tłum. Rafał J. Kupiszewski (doktorant Studium Biblijno-Pastoralnego UKSW w Warszawie, teologia moralna)

Tekst oryginału: Nochmals: Zulassung von wiederverheiratet Geschiedenen zu den Sakramenten? Ein dorniges und komplexes Problem, Stimmen der Zeit 233 (2015) 7, s. 435-445.

Key words: indissolubility of marriage, non-sacramental marriage, divorce, pastoral care of people in non-sacramental, access to Eucharist.

\section{Summary}

Kasper's article refers to his earliest statement during Consystorium in February 2014. He explicates some subjects connected with divorced people who got civil married again.

Translated by Julia H. Kupiszewska

Walter Kasper (1933), profesor teologii na Uniwersytecie w Tybindze i Münster, członek Międzynarodowej Komisji Teologicznej. Od 1989 biskup diecezji Rottenberg-Stuttgart, od 1999 sekretarz Papieskiej Rady ds. Popierania Jedności Chrześcijan, a następnie jej przewodniczący (2001-2010). Kreowany na kardynała w 2001. W 2007 otrzymał doktorat h.c. Uniwersytetu Opolskiego. Uznawany za głównego promotora na rzecz zmian w ocenie kościelnego statusu rozwiedzionych żyjących w nowych związkach. 